\title{
Combined Effect of Some Bio-Agents Against the Grasshopper, Hetiracris littoralis Under Semi-Field Condition
}

\author{
Aziza Sharaby ${ }^{1}$, Mohamed A. Gesraha ${ }^{1}$, Sayed A. Montasser ${ }^{2}$, \\ Youssef A. Mahmoud ${ }^{1}$, Sobhi A. Ibrahim ${ }^{1}$ \\ 1- Department of Pests \& Plant Protection, National Research Center, Dokki, Cairo, EGYPT \\ 2- Faculty of Agriculture, Al-Azhar University, Cairo, EGYPT
}

\begin{abstract}
L C_{50}$ of the alcoholic $80 \%$ extract of Euphorbia pulcharrima (Ephorbiaceae) (0.714\%),essential oil of Garlic plant Allium sativum (Liliaceae) (0.067\%)and entomopathogenic nematodes $\left(E P N_{s}\right)$ of Steinernima carpocapsae (Stienernematidae) and Heterorhabditis bacteriophora(Heterorahbditidae ) (500 IJs/ml), were tested for their solely and/or combined toxic effects and for their effects on some biological aspects against the grasshopper, Heteracris littoralis (Orthoptera: acrididae) $1^{\text {st }}$ instar nymphs under semi-field condition. The joint action of the mixture of the most effective extract (E. pulchrrima) and oil (Garlic oil) exhibit an antagonistic effect with co-toxicity index of (-24), despite the increase the proportion of death in the mixture for all the tested groups the type of interaction were antagonism, all the tested materials had variable mode of action which resulted in significantly antagonistic effects. Reviewing the obtained results, it can be concluded that the efficiency of the different tested bio-agents material mixture against the $1^{\text {st }}$ instar nymphs of $\mathrm{H}$. littoralis varied tremendously according to the type of compounds of the tested mixture. Euphorbia $80 \%$ methanol extract and Garlic oil may used separately or in combination as alternatives safe tools against $H$. littoralis grasshopper. Semi-field experiments cleared that nematodes in combination with the oil or extract increased the mortality percentage. The combination mixture of extract, oil and nematode significantly affected development, reproduction and life cycle of $\mathrm{H}$. littoralis. Lethal effect varied with regard to the nematode species. Semi-field experiment of the plant extract, plant oil and their mixture revealed some changes on the biological aspects, an increase in the nymphal period, pre-oviposition, oviposition and post-oviposition periods. There is vigorous decrease in the female fecundity and egg fertility. The control of the insect by nematode and sub-lethal dose of plant extract or plant volatile oil as biological control may enhance their lethal effect on insect pest when applied simultaneously. Combination mixture of the tested bio-agent could be considered as possible means for use in programs of integrated pest management of $\mathrm{H}$. littoralis grasshopper.

Keywords: Grasshopper, Heteracris littoralis, Entomopathogenic nematode, Steinernema, Heterorhabditis, Joint action, Biological aspects, Semi-field test. Plant extract, Essential oil, Euphorbia pulchrrima, Allium sativum.
\end{abstract}

\section{Introduction}

Botanical insecticides are one of the best alternatives for these hazardous chemicals. They are plantderive insecticides, either naturally occurring plant materials or the products simply derived from such plants (GUPTA et al., 2005). A number of medicinal plant species like Euphorbia sp., Dodonea vescosa, Eucalyptus sp. and Chinus trbinlitolia etc..., are known to possess insecticidal properties (SHARMA and GUPTA 2009; MAZEN et al., 2009; OPARAEKE, 2004; UwAEZUOKE, 2002 and CRUZE et al., 2000. Essential oils are volatile, natural, complex compounds characterized by a strong odor and are formed by plants as secondary metabolites. In nature, essential oils play an important role in protection of the plants as antibacterial, antiviral, antifungal, insecticides and also against herbivorous by reducing their appetite for such plants. They also may, attract some insects to favor the dispersion of pollens and seeds or repel undesirable others (BAKKALI et al., 2008). Therefore, the use of essential oils extracted from aromatic plants to control insect pests has been investigated and well documented (ISMAN, 2006; Koul et al., 2008; RAJENDRAN \& SRIRANJINI, 2008). The possibility of using pathogenic nematode to control destructive pest has been envisioned for a long time. From time to time efforts to institute the control of certain insects by such measures have been made in various parts of the world. In recent years there is a need to reappraise the possibilities of this method in the light of new technique and newer knowledge concerning the effect of pathogenic nematodes, plant essential oils and plant extracts on insect population and their control. Recently, most researches tend to use some strains of nematode and extracts of some plants for controlling grasshopper. The grasshopper, H. littoralis is one of the most harmful pests to different cultivated crops in Egypt. Its economic importance comes from attacking many vegetable cultivated areas even trees, feeding on it and causing great losses in quantity and quality of the attacked crops. In some cases thousands of cultivated hectares may be attacked by the swarms of grasshopper leaving it as a divested desert. The economic injury of $H$. littoralis in Egypt had been documented by MistiKaWY (1929) and NAKHLA 
(1957). Insecticide mixtures are usually applied in the field to enhance the spectrum of the control when multiple pests are attacking simultaneously. They are also recommended to increase the efficacy of the control of a single pest to delay the development of insecticide resistance or to combat current resistance in a pest species. Insecticide resistance has become a major obstacle to successful chemical control with conventional insecticides. The evolution of resistance to insecticides is governed by a complex of events and factors; mainly, intense and repeated applications of insecticides which are often from the same chemical group or which employ the same mode of action. To prevent the resistance phenomenon, there is a need for different compounds having different modes of action (FEI YI et al., 2012). Combined mixture of insecticides can be used in order to 1- The amount of material used can be reduced without loss of activity, 2- To delay the selection of resistant strains (GISI, 1991). The main aim of the present research is to evaluate the combined effect of three bio-agents (Garlic oil, Euphorbia extract and nematodes) on the grasshopper, H. littoralis under semi-field condition for disrupting growth and development of $H$. littoralis so that they can be used in the integrated handling of pests.

\section{1- Insect culture:}

\section{Materials \& Methods}

Heteracris littoralis grasshopper was reared under laboratory condition for several generations on semiartificial diet as mentioned by SHARABY et al. (2010). Essential oils Garlic, Allium sativum (Family: Liliaceae) were obtained from EL-Captain company (CAPPHARM), elcaptain@elcaptain Co., Al-Obour city (Cairo), Egypt. Plant of Euphorbia sp. was collected from the garden of National Research Centre, Egypt. The plant parts were dried in shad place then minced into powder in an elecreric mill then extracted with $80 \%$ methanol as mentioned by SHARABY et al. (2011). The tested nematode were obtained form the Plant Protection Laboratory, National Research Centre, Egypt.

2- Combined actions of the plant extract, essential oil and entomopathogenic nematode on H. littoralis under laboratory condition ;

The artificial diet that used for rearing $H$. littoralis and described by SHARABY et al. (2010) was mixed with the sub-lethal concentration $\left(\mathrm{LC}_{50}\right)$ that previously determined by SHARABY et al. (2011\&2012) of the different bio-agents (Euphorbia pulchrrima plant extract at concentration (0.714\%), Garlic, Allium sativa plant oil at concentration $(0.075 \%)$ and Steinernema carpocabsa or Heterorhabditis bacteriophora nematode (500 $\mathrm{IJs} / \mathrm{ml})$ ) separately and in combination. The treated diet for each treatment was introduced into the rearing cages each with $1001^{\text {st }}$ instar nymph of $H$. littoralis and left for feeding on the treated diet for 14 days, then the percentage of mortality was calculated. For the control test untreated diet was used. Corrected mortality was made according Abbott s formula (АВвотт, 1925). The combined action of the mixtures were expressed as cotoxicity factor which was estimated by equation of MANSOUR et al. (1966) as follows.

$$
\begin{aligned}
& \text { Co-toxicity factor }=\text { Observed } \% \text { mortality }- \text { Expected } \% \text { mortality } \\
& \text { Expected \% mortality }
\end{aligned}
$$

Where the observed \%mortality is the mortality of individuals treated by the mixture, expected $\%$ mortality is the sum mortalities of each material when used singly.

This factors was used to differentiates the results into 3 categories. A positive factor of 20 or more meant potentiating, a negative factor of 20 or more meant antagonism, and any intermediate value between $(-20$ and +20 ) was considered only additive effect.

\section{3- Semi-field experiment}

Effect of combination of different bio-agents on percentage of mortality and some biological aspects for the $1^{\text {st }}$ instar nymph of $H$. littoralis under semi- field condition:

A semi-field experiment was conducted outside the laboratory in the garden of National Research Centre under the natural condition during January until April, the average temperature was $29^{\circ} \mathrm{C}\left(20.5-37.0^{\circ} \mathrm{C}\right)$ and the photoperiod 10:14 light to dark. Assay units were pot-planted Clover, Trifoleum alexandrinum $40 \mathrm{~cm}$ high, one month old, twelve treatments were investigated in addition the control (untreated potted Clover), $0.05 \%$ Tween-80 was used as emulsifier. Water was used for the control test. Each treatment was assigned four times. Each potted plant was sprayed with $250 \mathrm{ml}$ of the sub-lethal concentration $\left(\mathrm{LC}_{50}\right)$ of solution of tested material in twelve different treatments (1- Garlic oil, 2- Euphorbia extract, 3- Steinernima nematode, 4Heterorhabditis nematode, 5- Garlic oil+ Euphorbia extract, 6- Garlic oil+Steinernima nematode, 7- Garlic oil+ Heterorhabditis nematode, 8- Euphorbia extract+Steinernima nematode, 9- Euphorbia extract 
+Heterorahabdetis nematode, 10- Garlic oil + Euphorbia extract + Steinernima nematode, 11- Garlic oil + Euphorbia extract + Heterorhabditis nematode, 12- Control (untreated). Spray treatment by using a hand sprayer 1 liter capacity, separately or in combination. The treated potted plants were placed under a wooden screen cages. Hundreds of 50 male with 50 females $1^{\text {st }}$ instar nymphs of $H$. littoralis were obtained from the standard laboratory culture then released inside the cages and left for feeding on the treated potted plant for 14 days, percentages of mortality was recorded for each treatment at intervals each 2 days. The potted plants were changed with another untreated new ones. Every treatment and control was replicated four times. Biological aspects were estimated for the remaining insect inside the cages till reached the adult stage and allowed for mating, oviposition and laying eggs, thin calculated the number of the first offspring $\left(\mathrm{F}_{1}\right)$ (new generation of $1^{\text {st }}$ instar nymphs).

\section{Statistical analysis}

Statistical, all data were subjected to analysis of Variance (ANOVA) through "SPSS" Computer Program. To differentiate between means, Duncan's multiple range test $(\mathrm{P}=0.05)$ was used (DunCAN, 1965).

\section{Results \& Discussion}

\section{1- Joint action of different bio-agents}

Table (1) revealed the presence of antagonistic effects between Garlic oil and Euphorbia extract in the combination mixture that was expressed as co-toxicity factors with (-24), for Steinernima nematode and Garlic oil (-44), for Heterorhabditis nematode and Garlic oil (-40), for Garlic oil, Euphorbia extract and Steinernima nematode (-47.9) and finally for Garlic oil, Euphorbia extract, Heterorhabditis nematode was (-48.88). Despite the increase in the proportion of death in the mixture for all the tested groups the type of interaction were antagonism. For example, in group1 percentage of mortality for $1^{\text {st }}$ nymph instar of $H$. littoralis that fed on artificial diet treated with Garlic oil as mentioned in the methods cleared 50\% and for Euphorbia extract was $45 \%$ while for their mixture was $55 \%$.

These result indicated that all the tested materials had variable mode of action which resulted in significantly antagonistic effects. Pesticides are grouped into classes of compounds that have similar chemical structure and modes of toxic action. The term (mode of toxic action) is defined as a series of key processes that begins with the interaction of a pesticide with a receptor site and proceed through on the operational and anatomical changes in an organism that result in sub lethal or lethal effects (EPA, 2000). GORDON and ELDEFRAWI (1960) speculated that antagonism could be produce if one insecticide interfere with the activation of the other by retarding it, so maximal effects were not arrived at simultaneously, and the detoxifying enzymes would have more chance to acting on the less toxic parent compound. HEWLETT (1960) suggested that independence of action, wither partial or complete, might be due to different speeds of action as well as to different sites of action. Mode of toxic action is essential in understanding how mixtures may act jointly. The effect of the tested materials may be due to the presence of some chemical groups in their structure e.g., alkaloids, tannins, mono and triterpenes and sterols (SCHMIDIT and WEMER, 1993). Co-toxicity action of the mixture have been based physical and chemical properties of the compound (ABDE-MAGEED and SHALABY, 2011). MANSOUR et al. (1966) recorded that the antagonistic pairs consisted mainly of 2 relatively strong insecticides, or combinations of 1 strong and 1 weak insecticides. Non of the pairs was of 2 weak or 2 very strong insecticides. One material may interfere with the activation of the other material, antagonism would occur. Table (1) indicated that the all tested materials were relatively strong, or one material was stronger than the other, or nearly equal in the combined mixture. Reviewing the obtained results, it can be concluded that the efficiency of the different tested bio agent material mixtures against the $1^{\text {st }}$ instar nymphs of $H$. littoralis varied tremendously according to the type of component of the tested mixtures. The effect of volatile and plant extracts may be attributed to one or more of the following, fumigants, contact or poisoning effect and may due to the presence of some chemical groups in their structure such alkaloides, tannins, mono and triterpenes, flavonodes, steroles, saponines and glycosides.

\section{2- Semi-field test}

Combined effect of different bio-agent under field condition on the mortality percentage of the $1^{\text {st }}$ instar nymph after feeding on Clove potted plant sprayed with $\mathrm{LC}_{50}$ concentration values.

Table (2) revealed that, the appearance of mortality started form the fourth day after the treatment for all treatments; garlic oil and Euphorbia extract gave nearly the same mortality percentage till twelve day then getting a small increase $45 \%$ for the oil and 50\% for the extract. Mixture of both oil with extract slightly increased mortality to 55\%. Mixture of each species of nematode Steinernema or Heterorhabditis with garlic oil and Euphorbia extract increased mortality percentage to 62.5 and 50\%, compared with 25 and $17.5 \%$ for 
Steinernema and Heterorhabditis, respectively if they singly used. This result indicated that the presence of garlic oil and Euphorbia extract in one mixture with Steinernema or Heterorhabditis nematode increased the mortality percentages of the $2^{\text {nd }}$ instar nymphs of $H$. littoralis when they mixed together in their diet. These results indicated that the presence of different mode of actions of the tested three bio-agents where the oil or the extract may activated the penetration of symbiotic bacteria of nematodes through the gut tissues to the haemolymph causing septicemia to the insect and increasing of insect mortality. These results agreed with that previously mentioned by ( SHARABY et al ,2012) they recorded that Garlic oil causing damages in different areas of the alimentary canal of H.littoralis this effect may reflect on activating the symbiotic bacteria and facilitating their penetration through the damaged area to reach the insect hemocoel and causing death. Also, the nematode cause damage for the insect tissues and facilitate the oil or the extract penetration into cell tissues and making their effects.

Table (1): Joint action of different bio-agents after mixed with artificial diet on the percentage mortality of $1^{\text {st }}$

\begin{tabular}{|c|c|c|c|c|c|c|}
\hline $\begin{array}{l}\text { Combined } \\
\text { group }\end{array}$ & Material & $\begin{array}{l}\text { Mortality } \\
(\%)\end{array}$ & $\begin{array}{l}\text { Expected } \\
\text { mortality } \\
(\%)\end{array}$ & $\begin{array}{l}\text { Observed } \\
\text { mortality } \\
(\%)\end{array}$ & $\begin{array}{l}\text { Co- } \\
\text { toxicity } \\
\text { factor } \\
\end{array}$ & $\begin{array}{l}\text { Joint action } \\
\text { category }\end{array}$ \\
\hline \multirow{3}{*}{1} & Garlic oil & 50 & \multirow[b]{3}{*}{95} & \multirow[b]{3}{*}{55} & \multirow[b]{3}{*}{-42} & \multirow[b]{3}{*}{ Antagonism } \\
\hline & Euphorbia extract & 45 & & & & \\
\hline & Garlic oil+ Euphorbia extract & 55 & & & & \\
\hline \multirow{3}{*}{2} & Nematode $(\mathrm{S})^{*}$ & 25 & \multirow[b]{3}{*}{75} & \multirow[b]{3}{*}{42} & \multirow[b]{3}{*}{-44} & \multirow[b]{3}{*}{ Antagonism } \\
\hline & Garlic oil & 50 & & & & \\
\hline & Nematode (S)+Garlic oil & 42 & & & & \\
\hline \multirow{3}{*}{3} & Nematode $(\mathrm{H}) * *$ & 17.5 & \multirow[b]{3}{*}{67.5} & \multirow[b]{3}{*}{40} & \multirow[b]{3}{*}{-40} & \multirow[b]{3}{*}{ Antagonism } \\
\hline & Garlic oil & 50 & & & & \\
\hline & Nematode $(\mathrm{H})+$ Garlic oil & 40 & & & & \\
\hline \multirow{3}{*}{4} & Euphorbia extract & 45 & \multirow[b]{3}{*}{70} & \multirow[b]{3}{*}{40} & \multirow[b]{3}{*}{-0.43} & \multirow[b]{3}{*}{ Antagonism } \\
\hline & Nematode $(\mathrm{S})$ & 25 & & & & \\
\hline & Nematode (S)+ Euphorbia extract & 40 & & & & \\
\hline \multirow{3}{*}{5} & Euphorbia extract & 45 & \multirow[b]{3}{*}{62.5} & \multirow[b]{3}{*}{32} & \multirow[b]{3}{*}{-0.49} & \multirow[b]{3}{*}{ Antagonism } \\
\hline & Nematode $(\mathrm{H})$ & 17.5 & & & & \\
\hline & Nematode $(\mathrm{H})+$ Euphorbia extract & 32 & & & & \\
\hline \multirow{4}{*}{6} & Garlic oil & 50 & \multirow[b]{4}{*}{120} & \multirow[b]{4}{*}{62.5} & \multirow[b]{4}{*}{-47.9} & \multirow[b]{4}{*}{ Antagonism } \\
\hline & Euphorbia extract & 45 & & & & \\
\hline & Nematode (S) & 25 & & & & \\
\hline & $\begin{array}{l}\text { Garlic oil+ Euphorbia extract } \\
+ \text { Nematode }(\mathrm{S})\end{array}$ & 62.5 & & & & \\
\hline \multirow{4}{*}{7} & Garlic oil & 50 & \multirow[b]{4}{*}{112.5} & \multirow[b]{4}{*}{57.5} & \multirow[b]{4}{*}{-48.88} & \\
\hline & Euphorbia extract & 45 & & & & \\
\hline & Nematode $(\mathrm{H})$ & 17.5 & & & & \\
\hline & $\begin{array}{l}\text { Garlic 0il+Euphorbia extract+ } \\
\text { Nematode }(\mathrm{H})\end{array}$ & 57.5 & & & & Antagonism \\
\hline
\end{tabular}

$$
\text { Nematode }(\mathrm{S})^{*}=\text { Steinernema } \text { Nematode }(\mathrm{H})^{* *}=\text { Heterorhabditis }
$$

These findings agreed with ABDEL-MAGEED et al. (2011) they recorded that insecticidal mixture are usually applied in the field to enhance the spectrum of control when multiple pests are attacking simultaneously. They are also recommended to increase the efficacy of the control of a single pest to delay the development of insecticide resistance or to combat current resistance in a pest species. To prevent the resistance phenomenon, there are need for different compounds having different mode of action (AYDIN and GURKAN, 2006). The rapid action of oils against some pests is indicative of a neurotoxic mode of action, and there is evidence for interference with the neuromodulator octopamine (KOSTYUKOVSKY et al., 2002). Plant extracts include alkaloids, terpenoids, phenols, flavonoids, and other minor chemicals can affect insects in several ways (LIN-ER et al., 1995). 
Table (2): Effect of sub lethal concentration of different bio agents on mortality percentage of $1^{\text {st }}$ instar nymphs of H. littoralis at intervals

\begin{tabular}{|l|l|l|l|l|l|l|l|}
\hline \multirow{2}{*}{ Tested material ( Treatments ) } & \multicolumn{7}{|c|}{ Mean \% Mortality at intervals (in days) } \\
\cline { 2 - 8 } & 2 & 4 & 6 & 8 & 10 & 12 & 14 \\
\hline \hline Euphorbia extract & 0 & 25 & 32.5 & 37.5 & 42.5 & 45 & $45 \mathrm{cb}$ \\
\hline Garlic oil & 0 & 25 & 30 & 37.5 & 45 & 50 & $50 \mathrm{~b}$ \\
\hline Euphorbia extract + Garlic oil & 0 & 15 & 37.5 & 50 & 55 & 55 & $55 \mathrm{~b}$ \\
\hline Steinernema nematode & 12.5 & 12.5 & 20 & 25 & 25 & 25 & $25 \mathrm{e}$ \\
\hline Steinernema + Garlic oil & 14.0 & 22 & 26 & 30 & 38 & 42 & $42 \mathrm{c}$ \\
\hline Sternernema + Euphorbia extract & 10 & 20 & 28 & 32 & 36 & 40 & $40 \mathrm{c}$ \\
\hline Stinernema + Garlic oil + Ephorbia extract & 0 & 15 & 47.5 & 57.5 & 62.5 & 62.5 & $62.5 \mathrm{a}$ \\
\hline Heterorhabditis nematode & 5 & 12.5 & 17.5 & 17.5 & 17.5 & 17.5 & $17.5 \mathrm{f}$ \\
\hline Heterorhabditis +Garlic oil & 12 & 16 & 22 & 32 & 36 & 40 & $40 \mathrm{c}$ \\
\hline Heterorhabditis + Euphorbia extract & 6 & 18 & 22 & 26 & 32 & 32 & $32 \mathrm{~d}$ \\
\hline $\begin{array}{l}\text { Heterorhabditis + Garlic oil + Euphorbia } \\
\text { extract }\end{array}$ & 0 & 17.5 & 42.5 & 50 & 50 & 50 & $50 \mathrm{~b}$ \\
\hline Control & 0 & 0 & 0 & 0 & 0 & 0 & 0 \\
\hline
\end{tabular}

Means \% mortality after 14 days that with the same letters within the treatments were not significantly difference $\mathrm{p}=0.05 \mathrm{LSD}=6.12$.

Combined effect of different bio agent under field condition on the biological aspects of the $1^{\text {St }}$ nymph instar after feeding on Clove potted plant sprayed with $\mathrm{LC}_{50}$ concentration values.

This experiment was conducted in order to determine the insecticidal activity of the most effective extract (Euphorbia) and the plant oil (Garlic oil) (Sharaby et al2011\&1012) and their combined mixture on the biological aspects of $H$. littoralis under semi-field condition. Data on Table (3) revealed a significant prolongation in the total nymphal period of $H$. littoralis that left for feeding of all the treated potted plants where it was 87.28, 98.93, and 100.13 days on the plants treated with Euphorbia extract, Garlic oil and the mixture of both (extract + oil), respectively compared with 63.52 days for the control untreated potted plants. Highly significant increasing was recorded for the pre oviposition period for their adults that emerged from nymphs that fed on the treated plants, it was 51.7 days for the mixture treated plants and 56.9, 59.9 days for the extract and for the oil respectively, when used separately compared to 23 days in the untreated checked plants. Highly reduction occurred in the oviposition periods for all treatment ranged from 16.71 to 23.50 days in comparing with 38.22 days for the control, decreasing of oviposition period making the adult deposited low number of eggs and decreased the population densities of the insect. Egg production by females were greatly decreased by the treatments they were 48.24, 57.90 and 50.00 eggs/female for the extract, oil and their mixture while they were $152.80 \mathrm{eggs} / \mathrm{female}$ for control test. Percentages of egg hatchability was vigorously affected by the three different treatments, it decreased form $94 \%$ for the untreated plants to $19.3 \%$ for the mixture treatment and for 25.6 and $30.5 \%$ in case of the extract and the oil treatment, respectively. Adult longevity was significantly decreased by the treatments it decreased from 104 days in the control to 114-127 days for the extract, oil and their combined mixture. Life span was greatly decreased from 183.00 in the control compared to 222.38-236.90 days for the extract, oil and the mixture. From the foregoing data it will be concluded that Euphorbia extract, Garlic oil, singly or in combination causing a great effect on the biological aspects of $H$. littoralis by increasing the total nymphal period, pre-oviposition, oviposition periods, life span, number of the deposited eggs and percentage of egg hatchability. Combination between the extract and the oil increased the total nymphal period and decreased the percentage of egg hatchability than if the two materials were used separately.

The obtained results showed that the combined mixture gave encouraging results against $H$. littoralis. This findings agrees with CASIDA (1990) who mentioned that the toxicity of phytochemicals depends on several factors among which are the chemical composition of the oil or extract and insect susceptibility. Some other different finding were reported by different scientists. FANG et al. (2002) thought the order of toxicity will often vary depending on the particular insecticide. The insecticidal activity of monoterpens, the major components of essential oils, has been reported against stored products insects (GARCIA et al., 2005). Many plant essential oils showed a broad spectrum of activity against pest insect ranging from insecticidal, antiffedant, repellent, oviposition deterrent, growth regulatory and antivector activities (KoUL et al., 2008). Also, they recorded that the same chemical constituents of the oils interfere with the octopaminergic nervous system in insects. Essential oil constituents are primarily lipophilic compounds that act as toxins, feeding deterrents and oviposition deterrents to a wide variety of insect pests (RICE and COAST, 1994). Secondary compounds in Euphorbia extract include alkaloids, terpinoids, phenolics, flavonoids, and their minor chemicals can affect $H$. littoralis in several ways. The mixture of Euphorbia extract and the Garlic oil proved possible insecticidal activity against $H$. littoralis. Further, while resistance development continues to be an issue for many synthetic pesticides, it is likely that resistance will develop more slowly to plant products based pesticides owing to complex mixture of 
constituents that characterize many of these products. Ultimately, it is in developing countries which are rich in endemic plant biodiversity that these pesticides may ultimately have their greatest impact in future integrated pest management programmes due to their safety to non-target organisms and environment. These substance are not only of low cost, but also have less environmental impact in term of insecticidal hazard. Our findings indicated that Euphorbia 80\% methanol extract and Garlic oil may used singly or in combination as alternatives safe tools against $H$. littoralis grasshopper.

Table (3): Effect of Euphorbia extract and Garlic oil on biological aspects of H. littoralis

\begin{tabular}{|c|c|c|c|c|c|}
\hline \multirow[b]{2}{*}{ Biological parameters } & \multicolumn{4}{|c|}{ Treatments $($ Mean \pm SE) } & \multirow[b]{2}{*}{ F-value } \\
\hline & Euphorbia & Oil & $\begin{array}{l}\text { Euphorbia+Oi } \\
1\end{array}$ & Control & \\
\hline $1^{\text {st }}$ instar nymph & $10.47 \pm 0.12 b$ & $10.50 \pm 0.14 \mathrm{~b}$ & $11.61 \pm 0.22 \mathrm{a}$ & $8.40 \pm 0.10 \mathrm{c}$ & $105.710^{* *}$ \\
\hline $2^{\text {nd }}$ instar nymph & $15.50 \pm 0.41 \mathrm{a}$ & $15.43 \pm 0.27 \mathrm{a}$ & $14.91 \pm 0.41 \mathrm{a}$ & $10.06 \pm 0.12 \mathrm{~b}$ & $109.221^{* * *}$ \\
\hline $3^{\text {rd }}$ instar nymph & $18.56 \pm 0.22 \mathrm{c}$ & $23.00 \pm 0.48 \mathrm{~b}$ & $24.48 \pm 0.73 \mathrm{a}$ & $12.94 \pm 0.12 \mathrm{~d}$ & $234.326^{* *}$ \\
\hline $4^{\text {th }}$ instar nymph & $20.59 \pm 0.40 \mathrm{~b}$ & $24.37 \pm 0.48 \mathrm{a}$ & $24.17 \pm 0.41 \mathrm{a}$ & $15.48 \pm 0.16 \mathrm{c}$ & $174.727^{* * *}$ \\
\hline $5^{\text {th }}$ instar nymph & $22.25 \pm 0.42 \mathrm{~b}$ & $25.27 \pm 0.42 \mathrm{a}$ & $25.00 \pm 0.37 \mathrm{a}$ & $16.54 \pm 0.14 \mathrm{c}$ & $193.255^{* *}$ \\
\hline $\begin{array}{llll}\begin{array}{l}\text { Total nymphal period (in } \\
\text { days) }\end{array} & & \\
\end{array}$ & $87.28 \pm 0.84 \mathrm{~b}$ & $98.93 \pm 0.97 \mathrm{a}$ & $100.13 \pm 1.36 \mathrm{a}$ & $63.52 \pm 0.31 \mathrm{c}$ & $549.865^{* * *}$ \\
\hline $\begin{array}{l}\begin{array}{l}\text { Pre-oviposition period } \\
\text { days) }\end{array} \\
\end{array}$ & $56.94 \pm 1.43 \mathrm{a}$ & $59.90 \pm 1.63 \mathrm{a}$ & $51.70 \pm 1.14 \mathrm{~b}$ & $23.00 \pm 0.15 \mathrm{c}$ & $326.665^{* *}$ \\
\hline Oviposition period (in days) & $16.71 \pm 0.51 \mathrm{c}$ & $19.10 \pm 0.59 \mathrm{c}$ & $23.50 \pm 0.89 \mathrm{~b}$ & $38.22 \pm 1.19 \mathrm{a}$ & $113.699 * *$ \\
\hline $\begin{array}{l}\text { Post-oviposition period (in } \\
\text { days) }\end{array}$ & $40.59 \pm 2.10 \mathrm{c}$ & $47.30 \pm 2.17 \mathrm{~b}$ & $56.00 \pm 0.87 \mathrm{a}$ & $42.48 \pm 0.68 \mathrm{c}$ & $16.865^{* *}$ \\
\hline No. of deposited eggs/female & $48.24 \pm 7.14 \mathrm{~b}$ & $57.90 \pm 6.57 \mathrm{~b}$ & $50.00 \pm 5.96 \mathrm{~b}$ & $152.83 \pm 2.68 \mathrm{a}$ & $111.476^{* *}$ \\
\hline Percentage of Egg hatchability & $25.59 \pm 3.78 \mathrm{bc}$ & $30.50 \pm 2.52 \mathrm{~b}$ & $19.30 \pm 3.34 \mathrm{c}$ & $94.04 \pm 0.51 \mathrm{a}$ & $225.921 * *$ \\
\hline Incubation period & $31.65 \pm 4.50 \mathrm{~b}$ & $50.30 \pm 5.30 \mathrm{a}$ & $24.40 \pm 0.93 \mathrm{~b}$ & $23.00 \pm 0.23 \mathrm{~b}$ & $12.854 * *$ \\
\hline Longevity (in days) & $114.03 \pm 1.57 \mathrm{c}$ & $118.37 \pm 1.41 \mathrm{~b}$ & $127.87 \pm 1.01 \mathrm{a}$ & $104.20 \pm 0.96 \mathrm{~d}$ & $61.506 * *$ \\
\hline Total mortality percentage & $0.56 \pm 0.16 \mathrm{c}$ & $1.67 \pm 0.14 \mathrm{a}$ & $1.00 \pm 0.22 \mathrm{~b}$ & $0.00 \pm 0.00 \mathrm{~d}$ & $24.844 * *$ \\
\hline Malformation percentage & $0.06 \pm 0.04 \mathrm{~b}$ & $0.00 \pm 0.00 \mathrm{~b}$ & $1.00 \pm 0.00 \mathrm{a}$ & $0.00 \pm 0.00 \mathrm{~b}$ & $94.542 * *$ \\
\hline Lifespan (in days) & $222.38 \pm 4.43 \mathrm{~b}$ & $\begin{array}{l}232.73 \pm 5.65 \\
\mathrm{ab}\end{array}$ & $236.91 \pm 3.85 \mathrm{a}$ & $183.32 \pm 3.62 \mathrm{c}$ & $27.548^{* *}$ \\
\hline
\end{tabular}

Same letters within the horizontal column were not significantly different $\mathrm{P}<0.05$

Date in table (4) show effect of entomopathogenic nematode, Steinernema carpocapsea separately or in combination with Garlic essential oil or $80 \%$ methanolic Euphorbia plant extract on some biological parameters of $H$. littoralis . The data cleared that there was increase in the total nymphal period, it lasted 70.8 day for the mixture of the all tested bio agents (S. carpocapsea+oil+ Euphorbia extract) and nematode+ extract 65.8 comparing with 63.5 day for control. Oviposition period decreased in all treatments if the bio-agents used separately or in combinations they ranged form 17.8-26.2 day in comparison with 38.2day in control. The mean number of deposited eggs/female significantly decreased in all treatments ranged from 63.5 to $73.0 \mathrm{egg} / \mathrm{female}$ comparing with 152.8 for the control. Highly significance obtained in the egg fertility it decreased by about $86 \%$ in case of treatment with nematode+extract, where it decreased to $72 \%$ in case treatment with mixture

Steinernema+oil+extract, where the lowest egg numbers was deposited. The longevity of adult is also differ from treatment to another, treatment with the mixture of the three bio-agents prolonged the longevity by about 16 days followed by treatment with mixture of Steinernema and Garlic oil which prolonged by about 12 days than the control while the two other treatment, Steinernema alone or in combination with the extract shortened the longevity by about 11 and 14 days than the control, respectively. The effect of Steinernema separately or in combination with Garlic oil and/or Euphorbia extract on mortality percent of adults and malformation of produced adult is so small that it can be neglected in relation to the control. It worthy to mention that, the positive effect of Steinernema when applied with Garlic oil on most biological parameters rather than application with other additives may be attributed to presence of Garlic oil which enhance or synergists the effect of Steinernema. 
Table (4): Combined effect of Euphorbia extract+Garlic oil+Steinernema nematode on biological aspects of H.littoralis

\begin{tabular}{|c|c|c|c|c|c|c|}
\hline \multirow{2}{*}{ Biological parameters } & \multicolumn{5}{|c|}{ Treatments (Mean \pm SE) } & \multirow{2}{*}{ F-value } \\
\hline & Steinernema & $\begin{array}{l}\text { Steinernema } \\
\text { +Oil }\end{array}$ & $\begin{array}{l}\text { Steinernema } \\
\text { +Euphorbia }\end{array}$ & $\begin{array}{l}\text { Steinernema } \\
\text { +Oil+Euphor } \\
\text { bia }\end{array}$ & Control & \\
\hline $1^{\text {st }}$ instar nymph & $9.69 \pm 0.15 \mathrm{c}$ & $10.35 \pm 0.17 \mathrm{~b}$ & $10.07 \pm 0.17 \mathrm{bc}$ & $11.27 \pm 0.22 \mathrm{a}$ & $8.40 \pm 0.10 \mathrm{~d}$ & $52.693 * *$ \\
\hline $2^{\text {nd }}$ instar nymph & $9.72 \pm 0.14 \mathrm{~d}$ & $11.38 \pm 0.14 \mathrm{c}$ & $11.83 \pm 0.19 \mathrm{~b}$ & $12.46 \pm 0.21 \mathrm{a}$ & $\begin{array}{l}10.06 \pm 0.12 \\
\mathrm{~d}\end{array}$ & $56.265^{* *}$ \\
\hline $3^{\text {rd }}$ instar nymph & $12.50 \pm 0.20 \mathrm{~cd}$ & $12.24 \pm 0.16 \mathrm{~d}$ & $13.17 \pm 0.17 \mathrm{ab}$ & $13.58 \pm 0.21 \mathrm{a}$ & $\begin{array}{l}12.94 \pm 0.12 \\
\text { bc }\end{array}$ & $8.759 * *$ \\
\hline $4^{\text {th }}$ instar nymph & $16.28 \pm 0.23 \mathrm{a}$ & $13.10 \pm 0.14 \mathrm{~d}$ & $14.47 \pm 0.13 \mathrm{c}$ & $15.19 \pm 0.24 \mathrm{~b}$ & $\begin{array}{l}15.48 \pm 0.16 \\
b\end{array}$ & $40.208 * *$ \\
\hline $5^{\text {th }}$ instar nymph & $16.91 \pm 0.17 \mathrm{~b}$ & $13.97 \pm 0.15 \mathrm{~d}$ & $16.17 \pm 0.17 \mathrm{c}$ & $18.23 \pm 0.40 \mathrm{a}$ & $\begin{array}{l}16.54 \pm 0.14 \\
b c\end{array}$ & $48.980 * *$ \\
\hline Total nymphal period (in days) & $64.16 \pm 0.96 \mathrm{bc}$ & $61.07 \pm 0.62 \mathrm{~d}$ & $65.77 \pm 0.48 \mathrm{~b}$ & $70.81 \pm 1.10 \mathrm{a}$ & $\begin{array}{l}63.52 \pm 0.31 \\
\mathrm{c}\end{array}$ & $24.296 * *$ \\
\hline Pre-oviposition period (in days) & $23.25 \pm 0.31 \mathrm{~d}$ & $60.60 \pm 1.59 \mathrm{a}$ & $33.64 \pm 0.98 \mathrm{c}$ & $50.00 \pm 1.05 \mathrm{~b}$ & $\begin{array}{l}23.00 \pm 0.15 \\
\mathrm{~d}\end{array}$ & $\begin{array}{l}457.722 * \\
*\end{array}$ \\
\hline Oviposition period (in days) & $26.17 \pm 0.58 b$ & $17.80 \pm 0.63 \mathrm{c}$ & $24.55 \pm 0.81 \mathrm{~b}$ & $25.20 \pm 0.95 \mathrm{~b}$ & $\begin{array}{l}38.22 \pm 1.19 \\
\mathrm{a}\end{array}$ & $58.550 * *$ \\
\hline Post-oviposition period (in days) & $47.50 \pm 1.10 \mathrm{~b}$ & $45.60 \pm 2.52 \mathrm{bc}$ & $40.36 \pm 1.32 \mathrm{~d}$ & $51.40 \pm 1.61 \mathrm{a}$ & $\begin{array}{l}42.48 \pm 0.68 \\
\text { cd }\end{array}$ & $9.555^{* *}$ \\
\hline No. of deposited eggs/female & $72.92 \pm 4.94 \mathrm{~b}$ & $64.60 \pm 5.95 \mathrm{~b}$ & $68.64 \pm 5.31 \mathrm{~b}$ & $63.50 \pm 5.22 \mathrm{~b}$ & $\begin{array}{l}152.83 \pm 2.68 \\
\mathrm{a}\end{array}$ & $\begin{array}{l}106.699 * \\
*\end{array}$ \\
\hline Percentage of Egg hatchability & $33.75 \pm 3.85 \mathrm{~b}$ & $37.90 \pm 3.26 \mathrm{~b}$ & $20.46 \pm 3.84 \mathrm{c}$ & $25.50 \pm 2.29 \mathrm{c}$ & $\begin{array}{l}94.04 \pm 0.51 \\
\mathrm{a}\end{array}$ & $\begin{array}{l}191.716^{*} \\
*\end{array}$ \\
\hline Incubation period & $24.08 \pm 2.28 \mathrm{c}$ & $44.20 \pm 2.47 \mathrm{a}$ & $35.64 \pm 1.16 \mathrm{~b}$ & $26.70 \pm 0.91 \mathrm{c}$ & $\begin{array}{l}23.00 \pm 0.23 \\
\mathrm{c}\end{array}$ & $40.828 * *$ \\
\hline Longevity (in days) & $92.97 \pm 0.86 \mathrm{c}$ & $116.90 \pm 1.90 \mathrm{a}$ & $89.93 \pm 1.64 \mathrm{c}$ & $\begin{array}{l}120.46 \pm 1.31 \\
\text { a }\end{array}$ & $\begin{array}{l}104.20 \pm 0.96 \\
\mathrm{~b}\end{array}$ & $94.084 * *$ \\
\hline Total mortality percentage & $0.56 \pm 0.36 \mathrm{a}$ & $0.72 \pm 0.34 \mathrm{a}$ & $0.67 \pm 0.39 \mathrm{a}$ & $0.92 \pm 0.43 \mathrm{a}$ & $0.00 \pm 0.00 \mathrm{a}$ & $1.678^{\mathrm{NS}}$ \\
\hline Malformation percentage & $0.00 \pm 0.00 \mathrm{~b}$ & $0.00 \pm 0.00 \mathrm{~b}$ & $0.00 \pm 0.00 \mathrm{~b}$ & $0.08 \pm 0.05 \mathrm{a}$ & $0.00 \pm 0.00 \mathrm{~b}$ & $2.850^{*}$ \\
\hline Lifespan (in days) & $165.28 \pm 3.65 \mathrm{c}$ & $\begin{array}{l}193.90 \pm 5.93 \\
\mathrm{ab}\end{array}$ & $168.60 \pm 4.95 \mathrm{c}$ & $\begin{array}{l}201.58 \pm 4.69 \\
\mathrm{a}\end{array}$ & $\begin{array}{l}183.32 \pm 3.62 \\
\mathrm{~b}\end{array}$ & $11.417^{* *}$ \\
\hline
\end{tabular}

$* *=$ Highly significant $*=$ Significant $\mathrm{NS}=$ not significant

Same letters within the horizontal column were not significantly different $(\mathrm{P}<0.05)$

Data in table (5) show the effect of another species of entomopathogenic nematode (Heterorhabditis) on some biological parameters of $H$. littoralis when applied separately or in a combination with the same previous agents, Garlic oil or Euphorbia extract. Data clear that application of entomopathogenic nematode, Heterorhabditis alone or with other agents led to slight differences in total nymphal period among treatments in relation to control, where there is an increase in nymphal period by about two days as in treatment with nematode alone to about 5 days as in treatment with mixture of nematode and Garlic oil with Euphorbia while treatment with nematode and Garlic oil led to decrease in nymphal period as a whole by about 2 days from the control. Treatment with Heterorhabditis nematode olane or mixed with the other additives had antagonistic effect on oviposition period where it decreased by about 12,18,12, 12 days as treatment with nematode alone, nematode and Garlic, nematode and Euphorbia extract and mixture of nematode and Garlic oil with Euphorbia extract, respectively. In case of female fecundity, it is observed that all treatments led to decrease the female fecundity by more than $50 \%$, where in the mixture of nematode and Garlic oil with Euphorbia treatment the percent decrease was about $68.2 \%$, about $59.2 \%$ in both nematode+Garlic oil and nematode+Euphorbia extract, and treatment with nematode alone led about $58 \%$ off in female fecundity. The incubation period was increased by different treatments in various degrees if compared with the control treatment. Longevity of the resulting adults of $H$. littoralis $\left(\mathrm{F}_{1}\right)$ increased in some treatments as in case nematode+Garlic oil which increased by about 23 days more than the control, and nematode+Garlic oil+Euphorbia extract which increased by about 17 days more than the control, while the other treatments led to decrease in the longevity by about 10.7 and 7.3 day less than the control in treatments of nematode alone and nematode+Euphorbia, respectively. 
Table (5): Combination of different bio-agent (Euphorbia extract+Garlic oil+ Heterorhabditis nematode) on biological aspects of $H$. littoralis

\begin{tabular}{|c|c|c|c|c|c|c|}
\hline \multirow{2}{*}{ Biological parameters } & \multicolumn{5}{|c|}{ Treatments (Mean \pm SE) } & \multirow{2}{*}{ F-value } \\
\hline & $\begin{array}{l}\text { Heterorhabdit } \\
\text { is }\end{array}$ & $\begin{array}{l}\text { Heterorhabditi } \\
\text { s +Oil }\end{array}$ & $\begin{array}{l}\text { Heterorhabditi } \\
\mathrm{s}+\text { Euphorbia }\end{array}$ & $\begin{array}{l}\text { Heterorhabditi } \\
\text { s } \\
+ \text { Oil+Euphorbi } \\
\text { a }\end{array}$ & Control & \\
\hline $1^{\text {st }}$ instar nymph & $9.65 \pm 0.14 \mathrm{c}$ & $10.57 \pm 0.21 \mathrm{~b}$ & $10.32 \pm 0.13 b$ & $11.39 \pm 0.19 \mathrm{a}$ & $8.40 \pm 0.10 \mathrm{~d}$ & $65.163 * *$ \\
\hline $2^{\text {nd }}$ instar nymph & $10.61 \pm 0.14 \mathrm{~d}$ & $11.33 \pm 0.19 \mathrm{c}$ & $11.94 \pm 0.16 \mathrm{~b}$ & $12.42 \pm 0.19 \mathrm{a}$ & $10.06 \pm 0.12 \mathrm{e}$ & $41.350 * *$ \\
\hline $3^{\text {rd }}$ instar nymph & $12.97 \pm 0.21 \mathrm{~b}$ & $12.27 \pm 0.19 \mathrm{~b}$ & $13.38 \pm 0.15 \mathrm{ab}$ & $13.49 \pm 0.19 \mathrm{a}$ & $12.94 \pm 0.12 \mathrm{c}$ & $7.475^{* *}$ \\
\hline $4^{\text {th }}$ instar nymph & $15.32 \pm 0.23 \mathrm{a}$ & $13.20 \pm 0.17 \mathrm{c}$ & $14.27 \pm 0.14 b$ & $14.64 \pm 0.21 \mathrm{~b}$ & $15.48 \pm 0.16 \mathrm{a}$ & $25.141 * *$ \\
\hline $5^{\text {th }}$ instar nymph & $16.68 \pm 0.22 \mathrm{a}$ & $14.33 \pm 0.14 \mathrm{c}$ & $15.53 \pm 0.19 \mathrm{~b}$ & $16.27 \pm 0.24 \mathrm{a}$ & $16.54 \pm 0.14 \mathrm{a}$ & $24.954 * *$ \\
\hline Total nymphal period (in days) & $65.10 \pm 0.56 b$ & $61.67 \pm 0.86 \mathrm{c}$ & $65.44 \pm 0.67 \mathrm{~b}$ & $68.33 \pm 0.95 \mathrm{a}$ & $63.52 \pm 0.31 \mathrm{~b}$ & $13.304 * *$ \\
\hline $\begin{array}{l}\text { Pre-oviposition period (in } \\
\text { days) }\end{array}$ & $23.83 \pm 0.35 \mathrm{c}$ & $50.70 \pm 2.08 \mathrm{a}$ & $36.08 \pm 0.68 b$ & $48.33 \pm 1.20 \mathrm{a}$ & $23.00 \pm 0.15 \mathrm{c}$ & $222.972 * *$ \\
\hline Oviposition period (in days) & $26.67 \pm 0.67 \mathrm{c}$ & $30.60 \pm 1.61 \mathrm{~b}$ & $26.50 \pm 0.74 \mathrm{c}$ & $26.08 \pm 1.13 \mathrm{c}$ & $38.22 \pm 1.19 \mathrm{a}$ & $25.004 * *$ \\
\hline $\begin{array}{l}\begin{array}{l}\text { Post-oviposition period } \\
\text { days) }\end{array} \\
\end{array}$ & $48.17 \pm 1.11 \mathrm{c}$ & $58.50 \pm 1.64 \mathrm{a}$ & $39.83 \pm 1.25 \mathrm{~d}$ & $52.25 \pm 1.27 \mathrm{~b}$ & $42.48 \pm 0.68 \mathrm{~d}$ & $41.609^{* * *}$ \\
\hline No. of deposited eggs/female & $60.42 \pm 7.29 b$ & $62.00 \pm 5.54 \mathrm{~b}$ & $62.08 \pm 5.95 b$ & $47.92 \pm 5.31 \mathrm{~b}$ & $152.83 \pm 2.68 \mathrm{a}$ & $102.460 * *$ \\
\hline Percentage of Egg hatchability & $34.58 \pm 3.11 \mathrm{~b}$ & $27.00 \pm 3.59 \mathrm{bc}$ & $30.83 \pm 4.08 \mathrm{~b}$ & $20.42 \pm 3.11 \mathrm{c}$ & $94.04 \pm 0.52 \mathrm{a}$ & $179.532 * *$ \\
\hline Incubation period & $24.92 \pm 0.94 \mathrm{c}$ & $43.70 \pm 2.53 \mathrm{a}$ & $31.25 \pm 1.57 \mathrm{~b}$ & $21.42 \pm 2.99 \mathrm{c}$ & $23.00 \pm 0.23 \mathrm{c}$ & $27.239 * *$ \\
\hline Longevity (in days) & $93.52 \pm 1.07 \mathrm{~d}$ & $127.50 \pm 2.01 \mathrm{a}$ & $96.97 \pm 1.19 \mathrm{~d}$ & $121.03 \pm 0.90 \mathrm{~b}$ & $104.20 \pm 0.96 c$ & $132.126 * *$ \\
\hline Total mortality percentage & $0.61 \pm 0.41 \mathrm{a}$ & $0.67 \pm 0.35 \mathrm{a}$ & $0.47 \pm 0.25 \mathrm{a}$ & $0.52 \pm 0.30 \mathrm{a}$ & $0.00 \pm 0.00 \mathrm{a}$ & $1.236^{\mathrm{NS}}$ \\
\hline Malformation percentage & $0.00 \pm 0.00 \mathrm{a}$ & $0.00 \pm 0.00 \mathrm{a}$ & $0.00 \pm 0.00 \mathrm{a}$ & $0.00 \pm 0.00 \mathrm{a}$ & $0.00 \pm 0.00 \mathrm{a}$ & $0.000^{\mathrm{NS}}$ \\
\hline Lifespan (in days) & $168.26 \pm 3.62 c$ & $202.90 \pm 6.09 a$ & $173.18 \pm 3.80 \mathrm{bc}$ & $195.94 \pm 3.40 \mathrm{a}$ & $183.32 \pm 3.62 b$ & $12.352 * *$ \\
\hline
\end{tabular}

Same letters within the horizontal column were not significantly different $\mathrm{P}<0.05$

Form the previous findings, we could be concluded that the tested plant extract (Euphorbia pulcharrima at $0.714 \%$ concentration), essential oil of Garlic plant (Allium sativum at $0.067 \%$ concentration) my be used separately or in combination for controlling $\mathrm{H}$. littoralis, also could be used in combination with the entomopathogenic nematode $S$. carpocapsa or Heterorhabditis or in simultaneous application during the integrated pest managements of $H$. littoralis for decreasing the appearance insect resistance and increase the insect mortality.

We believe that these types of studies are critical for realistic estimation of toxicity, because rarely are organisms exposed to only a single chemical in the field. This studies should be the focus of future researches.

\section{References}

[1]. Аввотт W.S. 1925. A method of computing the effectiveness of an insecticide. Journal of Economic Entomology., 18: 265-267.

[2]. ABdel-Mageed A.E.M, SH. E.M SHalaby. 2011. Toxicity and biochemical impacts of some new insecticide mixture on cotton leafworm Spodoptera littoralis (Boisd.). Plant. Protection. Sciences, 47 (4): 166-175.

[3]. Bakkali R., S. Averbeck, D. Averbeck, M .IDaOmar. 2008. Biological effects of essential oils. A review. Food and chemical Toxicology, 46: $446-475$.

[4]. CASIDA J.H. 1990. Pesticide mode of action, evidence for implications of a finite number of biochemical targets, in: J.E. Casida (Ed.), Pesticides and Alternatives, Innovative chemical and Biological Approaches to Pest Control, Elsevier, Amesterdam, pp. 11-22.

[5]. CRUZ M.E.S., H.M. NOZAKI, M.A. BatistA. 2000. Plantas Medicinais: Plantas Medicinais Alelopatia . Biotecnologia ci ênciae Desenvolvimento, 15: 28-34.

[6]. DunCAN D.B. 1965. Multiple range and multiple F-test. Biometrics, 11: 1-41.

[7]. EPA. 2000. Pesticide registration facts. Office of pesticide programs, U.S. Environmental protection agency, Washington, D.C., USA, Available online at USEPA Pesticide Registration.

[8]. FAnG L, B.H Subramanyam, F.H. ARTHUR. 2002. Effectiveness of spinosad on four classes of wheat against five stored product insects, Journal of Economic Entomology, 95: 640-650.

[9]. Fei Y.I., Z.O.U. ChunhuA, H.U. QIOGBo, H.U. MeIYing. 2012. The joint action of Destruxin and botanical insecticides (Rotenone, Azadirachtin and Paeonolum) against the cotton aphid, Aphis gossypii Glover. Molecules, 17: 7533-7542.

[10]. Garcia M., O.J. Donadel, C.E. ArdanaZ, E.C. TonN, M.E. Sosa. 2005. Toxic and repellent effects of Baccharis salicifolia essential oil on Tribolium castaneum, Pest Managament. Science, 61: 612-618.

[11]. GISI U. 1991. Synergism between fungicides for control of Phytophthora Pages 361-372 in: Phytophthora. J.A. Lucas, R. C. Shattock, D.S. Shaw, and L. R. Cooke, eds. Cambridge University Press, Cambridge.

[12]. GoRdon H.T., M.E. EldEFrawI. 1960. Analog. Synergism of several carbamate insecticides. Journal of Economic Entomology, 53 : 1001-1009.

[13]. GuPTA S., A.K. Sharma, A. Siorhi. 2005. Neem: A botanical pesticides. Indian Farmers, Digest, 32: 35-36.

[14]. Hewlett P.S. 1960. Joint action in pesticides, Pages 27-74 in: Advances in Pest Control Research. R. L, Metcalf, ed Vol. 3. John Wiley\& Sons, New York.

[15]. ISMAN M.B. 2006. Botanical insecticides, deterrents, and repellents in modern agriculture and an increasingly regulated world. Annual Review of Entomology, 51: 45-66. 
[16]. Kostyukovsky M., A. Rafaeli, C. Gileadi, N. Demchenko, E. ShaAyA. 2002. Activation of octopaminergic receptors by essential oil constituents isolated from aromatic plants: possible mode of action against insect pests. Pest Managament. Science, 58: 1101-1106.

[17]. Koul O., S. Walia, G.S. Dhaliwal. 2008. Essential oils as green pesticides: potential and constraints. Biopesticides International, 4(1): 63-84.

[18]. Lin-ER L., J.J.A. VAN LoON, L.M. Schoonhoven. 1995. Behavioral and sensory response to some Neem compounds by Pieris brassica larvae, Physiological .Entomology. 20: 143- 140.

[19]. Mansour Y.A., M.E. Eldefrawi, A. TOPPOZADZ, M. ZRID. 1966. Toxicological studies on the Egyptian cotton leaf worm Prodenia littura VI. Potentiation and antagonism of organophosphorus and carbamate insecticides. Journal of Economic Entomology, 59 (2): 307-311.

[20]. MAZEN A.A., M. AL-MARZAAwi, T.R. JAI, M.A. ShAtNAWI. 2009. Aqueous extracts of some medicinal plants are as toxic as imidacloprid to the sweet potato whitefly, Bemisia tabaci. Insect Science:9(15):1-6 (www.insectscience.org).

[21]. MistikAWY A. 1929. The locust problem in Egypt and its relation with other countries. Bullten Society Entomological Research, EEGYPT, 13: 29-41.

[22]. NAKHLA N.B. 1957. Das scicheingraben von Acrotylus longipes and A. insubricus (Orthoptera: Acrididae) Acta Zoology Hungkong, 5: 469-391.

[23]. OPARAEKE A.M. 2004. Collection, Identification and Screening of herbal extracts and waste matter for control of insect pests of cowpea, Vegna unguiculata (L.) Walp. Ph.D. Thesis, Ed,: Ahmadu Bello University, Zaria, pp. 330

[24]. RAJENDRAn S.A., V. SRIRANJINI. 2008. Plant products as fumigants for stored-product insect control. Journal of Stored Products Research, 44: 126-135.

[25]. RICE P.J., J.R. COAST. 1994. Insecticidal properties of several monoterpenoids to the housefly (Diptera: Muscidae), red flour beetle (Coleoptera: Tenebrionidae) and southern corn root-warm (Coleoptera: Chrysomelidae). Journal of Economic Entomology, 87: 11721179 .

[26]. SCHMidT O.T., F. WEMER. 1993. Flavogalloi and intermediate. Journal of Islamic Academy of Science, 6 (2): $149-154$.

[27]. Sharaby a, Sayed A. Montaser, Youssef. A. Mahmoud, SobHi. A. Ibrahim. 2012. Natural Plant Essential Oils for Controlling the Grasshopper (Heteracris littoralis) and their Pathological Effects on the Alimentary Canal. Ecologia Balkanica Gournal, 4( 1): 3952.

[28]. Sharaby A., S.A. Montaser, M.M. Shamseldean, Y.A. Mahmoud, S.A. Ibrahim. 2011. Plant Extracts as Alternative Botanical Insecticides for control the Grasshopper Heteracris littoralis with reference to histological changes on the Reproductive System. Journal of Basic Appllied Scientific Research, 1(9): 103-1038.

[29]. Sharaby A., S.A. MONTASER, Y.A. MAhMOUD, S.A. IBRAhIM. 2010. The possibility of rearing the grasshopper Heteracris littoralis (R.) on semi-synthetic diets. Journal of Agriculture and Food Technology, 1(1):1-7.

[30]. Sharma A., R. GuPTA. 2009. Biological activity of some plant extracts against Pieris brassica (Linm.). J. Biopesticides, 2 (1): $26-31$.

[31]. UWAEZUOKE D.C. 2002. Potential of plant extracts for control of flea beetle, Podagtica spp. on okra plant, H.N.D. Dissertation, Ed; College of Agriculture, AhmadubBello University, Zaria, $36 \mathrm{pp}$.

[32]. Cairo, EGYPT 